\title{
PERANCANGAN MESIN PENGOLAH AIR BERSIH BERGERAK DENGAN MENGGUNAKAN SISTIM MODULAR UNTUK PENANGGULANGAN KEADAAN DARURAT AIR
}

\author{
Yuliar Yasin Erlangga ${ }^{1}$, Heri Setiawan ${ }^{2}$ \\ ${ }^{1}$ Jurusan Teknik Perancangan Manufaktur, Politeknik Manufaktur Negeri Bandung, Bandung \\ 40135 \\ E-mail : uwie@polman-bandung.ac.id \\ ${ }^{2}$ Jurusan Teknik Manufaktur, Politeknik Manufaktur Negeri Bandung, Bandung 40135 \\ E-mail : heris@polman-bandung.ac.id
}

\begin{abstract}
ABSTRAK
Pengolahan air bersih (Water Treatment) sistem modular/mobile (compact mobile) merupakan pengembangan dari sistem penyaringan air dengan sistem "up flow" yang sudah dikembangkan oleh BPPT dengan penambahan dan perbaikan fungsi proses dalam upaya mengoptimalkan proses pengolahan air baku menjadi air bersih. Pengembangan yang dilakukan pada penelitian ini yaitu dengan mengubah dari instalasi pengolahan yang tetap yang biasanya berbentuk civil work ke dalam sub fungsi-fungsi pengolah yang bersifat modular/mobile (compact mobile) dengan ukuran / dimensi yang tidak terlalu besar (compact design). Keuntungan yang bisa didapatkan dari sistem tersebut terutama dalam segi penanganan selama proses pengolahan dan dalam hal penyediaan suku cadang yang mudah sehingga waktu perbaikan disaat terjadi kerusakan pada mesin pengolahan air bersih ini menjadi sangat singkat dan juga ukuran / dimensi dari perangkat ini yang cukup kecil (compact) sehingga mudah dalam pemindahan antar lokasi untuk keadaan darurat air. Pada akhir penelitian ini setelah melalui proses perancangan menurut VDI 2222 dan sudah dilakukan penilaian berdasarkan beberapa aspek maka terbangun sebuah prototipe modular mobile water treatment berkapasitas pengolahan $1 \mathrm{M}^{2}$ per jam yaitu rancangan nomer 2 dengan nilai 92\%. Aspek terbarukan yang dipelajari adalah desain modular mobile water treatment itu sendiri, penentuan dan pemilihan solusi dari sub fungsi bagian serta bagaimana subsub fungsi bagian tersebut diikatkan pada rangka sehingga instalasi tersebut menjadi kompak untuk dijadikan sebagai mobile water treatment.
\end{abstract}

Kata kunci: compact mobile water treatment, up-flow filtering process

\begin{abstract}
Water Treatment with a modular / mobile (compact mobile) water treatment system is the development of a water upflow system developed by BPPT with the addition and improvement of process functions in an effort to optimize the raw water treatment process into clean water. The development carried out in this research is to change the form from a fixed processing installation which is usually in the form of civil work into modular sub-function / mobile (compact mobile) that size / dimension is not too big (compact design). The advantages that can be obtained from the system especially in terms of handling during processing and in terms of spare parts supply so that the expected time of repair in the event of damage to the water treatment machine is very short and also the size / dimensions of this device is small enough (compact) so it is easy to transfer between locations for emergency water condition. At the end of this study after going through the design process according to VDI 2222 and has been assessed based on several aspects, there'll be a prototype modular mobile water treatment with a processing capacity of $1 M^{2}$ per hour with a design value of $92 \%$. The renewable aspect studied is the modular mobile water treatment design itself, the determination and selection of solutions from the sub-functional part and how the sub-functions of the parts are tied to the framework so that the installation becomes compact to serve as mobile water treatment.
\end{abstract}

21 Erlangga, Yuliar Yasin., dkk; Perancangan Mesin Pengolah Air Bersih Bergerak Dengan Menggunakan Sistim Modular Untuk Penanggulangan Keadaan Darurat Air 
Key words : compact mobile water treatment, up-flow filtering process

\section{PENDAHULUAN}

Sebagian besar kondisi masyarakat Indonesia masih bermasalah dengan air bersih. Masyarakat pada umumnya memanfaatkan air sumur untuk kebutuhan makan minum dan kegiatan MCK. Namun kualitas inputan sumber air dari sumur belum sesuai dengan standar yang ada. Hal ini akan sangat mengganggu kepada kesehatan masyarakat kalau dikonsumsi secara jangka panjang dan akan mengakibatkan dampak yang buruk terhadap aspek kehidupan yang lain (ekonomi, sosial dan juga budaya) (Effendi Hefni, 2003:11).

Dalam rangka meningkatkan kebutuhan dasar masyarakat mengenai kebutuhan akan air bersih, maka perlu diusahakan proses pengolahan dan pengelolaan air yang sesuai dengan karaktristik keadaan sekitar. Karakteristik utama yang perlu diperhatikan adalah sumber air baku yang tersedia serta pemilihan teknologi yang sesuai. Begitu banyak teknologi pengolah air minum (water treatment) yang telah dilakukan, namun masih ditemukan bermacam kendala yang berakibat pada tuntutan perbaikan, seperti : biaya yang relatif mahal, mekanisme yang statis (diam di tempat), energi pengolahan yang besar dan lain-lain (Herlambang, 2010). Beberapa tipe pengolahan air bersih yang teknologinya menyesuaikan dengan inputan air baku yang akan diolah seperti air laut, payau, danau, sungai dan sumur, dengan hasil keluaran yang diinginkan air bersih dan atau bahkan air minum (Said, dkk, 2005).

Salah satu teknologi pengolahan air bersih di pedesaan yang banyak diterapkan di Indonesia adalah teknologi saringan pasir lambat (sarpalam) konvensional (aliran dari atas ke bawah, down flow). Teknologi sarpalam yang lebih baik adalah sarpalam up flow (Herlambang \& Said, 2005).

Teknologi sarpalam up flow telah diterapkan oleh Herlambang dan Said (2005) dengan menggunakan konstruksi sipil dengan kapasitas pengolahan $100 \mathrm{~m} 3 /$ hari. Sedangkan teknologi sarpalam yang pernah diterapkan dengan konstruksi mekanik adalah teknologi sarpalam down flow untuk sistim penjernih air sampai dengan siap minum yang mobil telah diaplikasikan oleh Indriatmoko \& Widayat (2007). Teknologi ini menggunakan teknologi aerasi, koagulasi dan filtrasi.

Kualitas air ditentukan oleh banyak faktor, yaitu zat yang terlarut, zat yang tersuspensi, dan makhluk hidup, khususnya jasad renik, didalam air. Air murni, yang tidak mengandung zat yang terlarut, tidak baik bagi kehidupan. Sebaliknya zat yang terlarut ada yang bersifat racun. Apabila zat yang terlarut, zat yang tersuspensi dan makhluk hidup dalam air melebihi ketentuan yang berlaku, maka air tersebut disebut tercemar (Effendi Hefni,2003).

Saat ini telah dibuat standar untuk menentukan kualitas air baik itu secara fisik, kimiawi dan biologi yang diterapkan oleh Kementrian Kesehatan R.I. dan badan kesehatan dunia (WHO). Berdasarkan standar tersebut, air yang layak untuk digunakan haruslah bebas dari kuman penyakit, bakteri-bakteri patogen, jernih, tidak berasa, berbau dan tidak korosif serta juga tidak meninggalkan endapan pada jaringan distribusi yang dilaluinya.

Dalam usaha mendapatkan kuantitas dan kualitas air bersih yang memenuhi standar diperlukan mesin pengolah, baik itu berupa proses kimia atau dengan metoda penyaringan dengan media pasir silika, pasir ziolit atau karbon aktif. Melihat pada beragamnya kondisi dan kapasitas air baku yang tersedia, serta beragam topografi dan kemudahan akses, maka diperlukan untuk mengembangkan mesin yang sudah ada menjadi sebuah mesin pengolah air yang dapat menghasilkan air bersih dengan desain yang compact mobile, mudah pengoprasiannya dan relatif murah, serta fleksibel dalam artian mudah dipindahkan, mudah dipasang, mudah ditingkatkan kapasitasnya dan mudah dalam pemeliharaannya.

\section{TINJAUAN PUSTAKA}

\section{Metode Perancangan}

Proses pemecahan masalah yang optimal memerlukan tahapan kerja yang sistematik. Pekerjaan yang ada dapat dirumuskan dengan benar dan keterkaitan fungsi produk teknik yang dirancang dapat dimengerti dengan mudah. Metoda perancangan yang digunakan adalah Verein Deutsche Ingenieuer (VDI 2222) seperti diperlihatkan pada gambar 1.

22 Erlangga, Yuliar Yasin., dkk; Perancangan Mesin Pengolah Air Bersih Bergerak Dengan Menggunakan Sistim Modular Untuk Penanggulangan Keadaan Darurat Air 


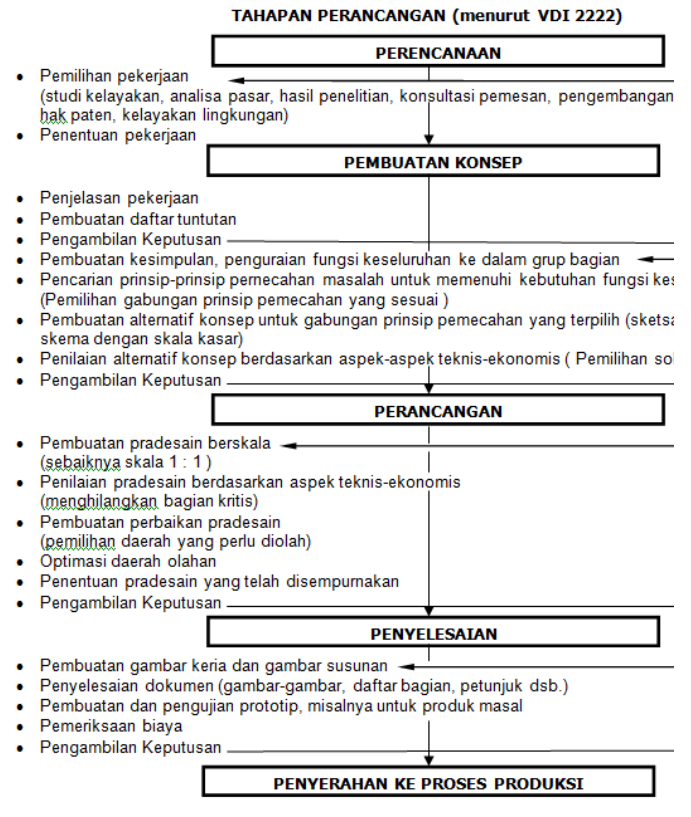

Gambar 1 Metode Perancangan VDI 2222

\subsection{Perencanaan}

Tahap perencanaan dilakukan sebagai awal dalam menentukan langkah kerja untuk menentukan beberapa faktor yang berpengaruh dalam melakukan analisa berupa pemilihan pekerjaan diantaranya studi kelayakan, analisis pasar, konsultasi pemesan, hak paten, kelayakan lingkungan, dan dilanjutkan dengan penentuan pekerjaan.

\subsection{Pembuatan konsep}

Dalam tahap pembuatan konsep, beberapa aktivitas yang berhubungan dengan perancangan tool dilakukan berdasarkan spesifikasi produk yang telah ditetapkan.

a. Penjelasan pekerjaan

Merupakan rumusan masalah atau tugas. Memperjelas masalah atau tugas yang akan diproses secara logis.

b. Pembuatan daftar persyaratan

Daftar persyaratan dibuat untuk memudahkan dalam proses perancangan, sehingga konstruksi yang dirancang tercapai secara maksimal.

c. Pembagian fungsi

Rancangan dikelompokkan berdasarkan fungsi, dimensi atau bentuk sesuai daftar tuntutan .

d. Pembuatan alternatif fungsi bagian Alternatif fungsi bagian dibuat sebagai bentuk lain dari fungsi yang telah ada yang bertujuan menghasilkan beberapa alternatif dari fungsi bagian disertai kelebihan- kelebihan maupun kekurangan-kekurangan dari setiap alternatif tersebut.

e. Pembuatan variasi konsep

Variasi konsep merupakan penggabungan beberapa alternatif yang dibuat sehingga membentuk suatu fungsi bagian.

f. Penilaian variasi konsep konstruksi

Variasi konsep yang ada dinilai berdasarkan aspek-aspek pada fungsi, kemudahan pembuatan, kemudahan penanganan, kemudahan perakitan, kemudahan perawatan dan biaya yang murah.

g. Pembuatan konsep pemecahan

Hasil dari penilaian yang terbaik dijadikan sebagai konsep pemecahan.

\subsection{Perancangan}

Berdasarkan konsep pemecahan, dilakukan perancangan konstruksi dengan memperhatikan beberapa faktor, yaitu: fungsi (function), pembuatan (manufacture), penanganan (handling), perakitan (assembling), perawatan (maintenance) dan biaya (cost)

Hasil rancangan ditampilkan berupa gambar draft, perhitungan konstruksi dilakukan berdasarkan gambar draft untuk mencapai hasil rancangan yang diinginkan.

\subsection{Penyelesaian}

Setelah rancangan selesai, maka tahap penyelesaian akhir yang harus dilakukan adalah sebagai berikut: pembuatan gambar susunan, pembuatan gambar bagian dan pembuatan daftar bagian

\section{Umum}

Air bersih yang biasa digunakan sehari-hari biasanya berasal dari sumber-sumber air bersih yang ada di alam kemudian diolah untuk mencapai standar kualitas tertentu.

Mengacu pada Peraturan Mentri Keehatan No. 416 Tahun 1990, tentang syarat-syarat Dan Pengawasan Kualitas Air yang dimaksud dengan air bersih adalah air yang digunakan untuk keperluan sehari-hari yang kualitasnya memenuhi syarat kesehatan dan dapat diminum apabila telah dimasak. Kualitas air harus memenuhi syarat kesehatan yang meliputi persyaratan mikrobiologi, fisika, kimia dan radioaktif.

\section{Koloid}

\subsection{Karakteristik Koloid}

Ciri Penting dari suatu koloid padat yang terdispensi (tersebar) dalam air yaitu partikelpartikel padat yang tidak akan mengendap karena gaya gravitasi. Ukuran partikelnya 
berkisar 0,1 milimikron (0,1x10-4) sampai 100 mikron (0,1×10-6). Karena koloida-koloida ukuran partikelnya berkisar satu milimikron sampai satu mikron, maka pecahan dari zat padat yang tidak biasa mengendap ini merupakan partikel koloid (Reynold 1982).

\subsection{Mekanisme Destabilisasi Koloid}

Kestabilan koloid tergantung pada resultan gaya tarik menarik dan gaya tolak menolak yang bekerja pada partikel -partikel koloid. Kation tertarik oleh anion partikel koloid tersebut, sedangkan anion yang lain akan tertolak setelah maksimum adsorbs tercapai. Keseimbangan tercapai apabila sejumlah kation mendekati permukaan koloid yang bermuatan negatif (anion), sedangkan ion lainnya terdistribusi pada lapisan selanjutnya. Pada jarak tertentu dari permukaan koloid akan terdapat konsentrasi anion dan kation yang sama besar sehingga suasana netral.

\subsection{Koagulasi dan flokulasi}

Agar terjadi tumbukan antar partikel koloid, maka daya tolak menolak diantara partikelpartikel yang bermuatan negatif harus dinetralkan dengan menambahkan koagulan yang bermuatan positif (Linvil, 1965). Proses penambahan koagulan tersebut dinamakan koagulasi. Menurut Eichekenfelder 1985, koagulasi adalah proses kimia yang digunakan untuk menghilangkan bahan cemaran yang tersuspensi atau dalam bentuk koloid.

Flokulasi menurut IUPAC adalah proses kontak dan adhesi antara partikel sehingga membentuk partikel dengan ukuran yang lebih besar. Partikel yang berada dalam keadaan tidak stabil akan cepat tergumpal. Akan tetapi apabila semua partikel dalam keadaan tidak stabil, maka proses flokulasi akan berjalan lambat. Untuk memungkinkan terjadinya penetralan partikel bermuatan oleh logam Trivalen yang bermuatan positif, maka konsentrasi muatan harus cukup agar gaya tarik menarik antar muatan yang berlawanan akan meningkat. Cara memperkecil jarak antar partikel atau menambah frekuensi tumbukan antar partikel adalah dengan pemberian gaya atau poer input sehingga air tersebut mengalami turbulensi.

\subsection{Sedimentasi}

Sedimentasi adalah pemisahan padatan dan cairan dengan menggunakan pengendapan secara gravitasi untuk memisahkan partikel tersuspensi yang terdapat dalam cairan tersebut (Reynols, 1982). Proses ini sangat umum digunakan pada instalasi pengolahan air minum.
Aplikasi utama dari sedimentasi pada instalasi pengolahan air minum adalah :

Pengendapan awal dari air permukaan sebelum pengolahan oleh unit saringan pasir cepat.

Pengendapan air yang telah melalui proses koagulasi dan flokulasi pada instalasi yang menggunakan sistim pelunakan air oleh kapursoda.

\subsection{Filtrasi}

Filtrasi adalah proses pengolahan yang dipakai untuk memisahkan materi-materi padatan (kotoran) berupa suspended solid (zat padat tersuspensi) dengan melewatkan air melalui suatu media. Melalui filter ini kualitas air dapat mencapai turbiditas kurang dari 0.1 NTU. Walaupun kurang dari $90 \%$ kekeruhan dan warna dipisahan dalam koagulasi dan sedimentasi, namun sejumlah flok masih terbawa keluar dan ini memerlukan pemisahan lebih lanjut (Linvil, 1963).

\subsection{Desinfeksi}

Desinfektan didefinisikan sebagai bahan kimia atau pengaruh fisika yang digunakan untuk mencegah terjadinya infeksi atau pencemaran jasad renik seperti bakteri anti virus, juga untuk membunuh atau menurunkan jumlah mikroorganisme atau kuman penyakit lainnya (Skima, 2008). Umumnya pada instalasi klor akan diperoleh dalam bentuk padatan dengan rumus kimia $(\mathrm{Ca}(\mathrm{OCl}) 2$. Sebelum dibubuhkan ke dalam air baku klor ini akan dilarutkan terlebih dahulu dalam air. Penggunaan klor secara luas untuk desinfeksi air karena (Linvil, 1963) mudah diperoleh baik dalam bentuk padat, cair maupun gas, selain itu hargannya yang relative murah juga mudah diterapkan karena kelarutannya relatif tinggi $(7000 \mathrm{mg} / \mathrm{l})$, dapat memberikan sisa klor dalam batas $(0,2$ s.d. $0,5 \mathrm{mg} / \mathrm{l})$ yang tidak membahayakan manusia.

\subsection{Parameter Kualitas Air}

Pemeriksaan kualitas air dilakukan terhadap parameter-parameter penting yang dapat menggambarkan karakteristik dari air tersebut sesuai dengan tujuan pemeriksaan. Parameterparameter yang diukur adalah: kekeruhan, warna, $\mathrm{pH}$, Besi, Detergen dan Zat Organik.

\section{METODOLOGI}

Penelitian ini melakukan perancangan dan pembuatan prototipe mesin pengolah air bersih sistem mampu pindah (mobile) untuk kepentingan saat bencana (darurat air). Penelitian difokuskan pada penyempurnaan dari hasil penelitian 
sebelumnya, yaitu pada konsep rancangan dan jenis teknologi yang digunakan. Penyempurnaan rancangan dilakukan terutama pada hal mengatasi masalah-masalah : kualitas air yang sangat berhubungan dengan teknologi proses, laju aliran air yang menentukan kapasitas produksi pengolahan air berupa debit dan juga dari segi rancang bangun untuk mencapai tujuan yang diinginkan yaitu berbentuk modular. Modularitas yang dimaksud tidak hanya pada unit keseluruhannya, tetapi juga pada setiap fungsi bagiannya agar mudah untuk dilepas pasang dari instalasi keseluruhan.

Untuk mengurangi aktifitas manufaktur dan meminimalkan biaya yang digunakan, diharapkan banyak menggunakan part standar termasuk didalamnya adalah tangki untuk penyadap air, ventury, konstruksi pengatur dosis, static mixer, filter dan juga penampung air olahan yang berupa air bersih.

Mesin instalasi pengolah air ini terbagi menjadi beberapa sub fungsi bagian, dimana masing-masing sub fungsi bagian ini mempunyai kekhususan fungsi dan harus merupakan kesatuan tersendiri yang mampu dibongkar pasang dengan tidak menggangu fungsi bagian lain. Hubungan satu dengan yang lainnya didefinisikan dengan sistem masukan dan luaran setelah melalui proses pengolahan per fungsi bagian tersebut. Fungsi bagian tersebut terdiri dari:

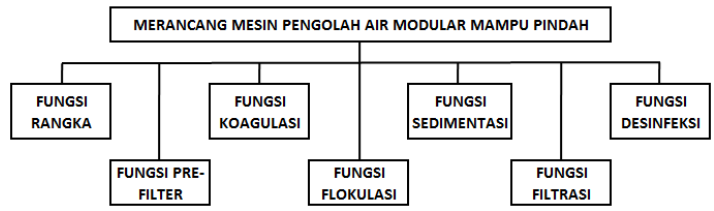

Gambar 2 Fungsi Bagian

Perancangan sistem diteliti mengacu kepada konsep-konsep yang sudah ada dan dimodifikasi dengan kriteria dan prasyarat yang sudah ditentukan seperti luaran air yang baik, kapasitas air, indikator-indikator hasil olahan air yang harus mengacu pada standar baku mutu air.

Perancangan manufaktur didesain sedemikian rupa sehingga mencapai tujuan yang yang diinginkan yaitu mudah untuk dipindakan (portable) dengan kapasitas air yang cukup signifikan untuk kebutuhan hidup per hari. Kemudian seluruh parameter rancangan akan diterapkan pada pembuatan prototipe dan hasilnya di analisis.

Berikut ini adalah diagram alir langkahlangkah pelaksanaan penelitian.

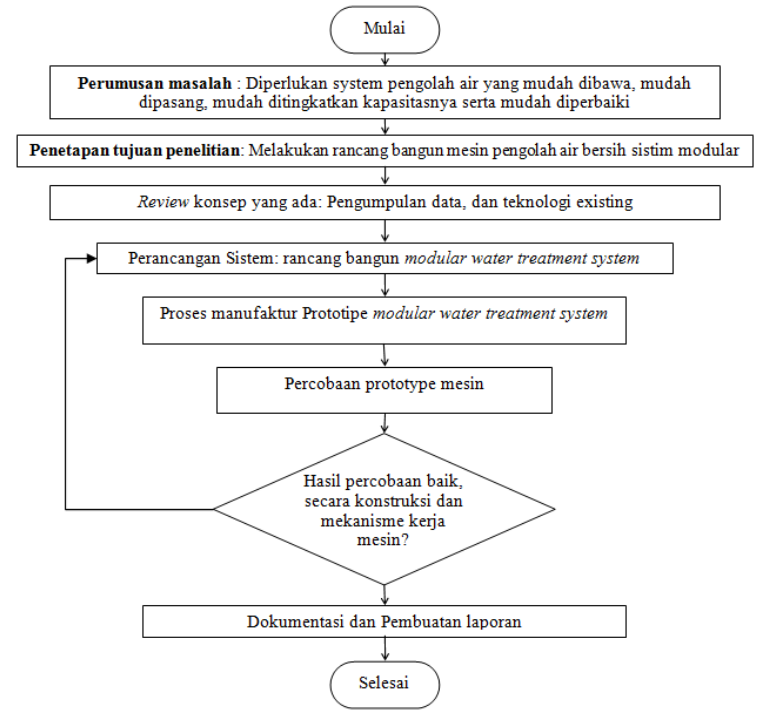

Gambar 3 Diagram alir

\section{PEMBAHASAN}

1. Proses Perancangan

1.1 Fungsi Bagian Rangka

Rangka yang dibuat dipilih berdasarkan beberapa alternatif seperti tabel 1 berikut:

Tabel 1 Alternatif fungsi bagian rangka

\begin{tabular}{|c|c|c|c|c|}
\hline $\begin{array}{c}\text { Fungsi } \\
\text { Bagian }\end{array}$ & Alt. 1 & Alt. 2 & Alt. 3 & Alt. 4 \\
\hline \multirow{3}{*}{ RANGKA } & DI BAUT & DI LAS & DI KELING & DI COR \\
& & & \\
& & & \\
\hline
\end{tabular}

1.2 Fungsi Bagian Pre-filter

Proses pre-filter dipilih berdasarkan beberapa alternatif seperti tabel berikut:

Tabel 2 Fungsi bagian pre-filter

\begin{tabular}{|c|c|c|c|c|}
\hline $\begin{array}{c}\text { Fungsi } \\
\text { Bagian }\end{array}$ & Alt. 1 & Alt. 2 & Alt. 3 & Alt. 4 \\
\hline \hline \multirow{2}{*}{ PREFLTER } & CYCLON & SCREEN PAB & STANDAR PRODUK & PLATYPUS \\
& & & & \\
& & &
\end{tabular}

\subsection{Fungsi Bagian Koagulasi}

Proses koagulasi dipilih berdasarkan beberapa alternatif seperti tabel berikut: 
Tabel 3 Alternatif fungsi bagian koagulasi

\begin{tabular}{|c|c|c|c|c|}
\hline $\begin{array}{l}\text { Fungsi } \\
\text { Bagian }\end{array}$ & Alt. 1 & Alt. 2 & Alt. 3 & Alt. 4 \\
\hline KOAGULASI & 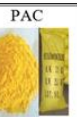 & 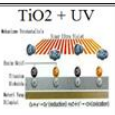 & $\begin{array}{l}\text { ELEKTROMAGNETIK } \\
\text { ION Fe/Mg }\end{array}$ & DNA ENZYM \\
\hline
\end{tabular}

\subsection{Fungsi Bagian Flokulasi}

Proses Flokulasi dipilih berdasarkan beberapa alternatif seperti tabel berikut:

\section{Tabel 4 Alternatif fungsi bagian flokulasi}

\begin{tabular}{|c|c|c|c|}
\hline $\begin{array}{c}\text { Fungsi } \\
\text { Bagian }\end{array}$ & Alt. 1 & Alt. 2 & Alt. 3 \\
\hline \hline \multirow{3}{*}{ FLOKULASI } & ZIG - ZAG & PENGADUKAN & SELANG \\
& 0 & & \\
& 3 & & \\
\hline
\end{tabular}

\subsection{Fungsi Bagian Sedimentasi}

Proses Sedimentasi dipilih berdasarkan beberapa alternatif seperti tabel berikut:

Tabel 5 Alternatif fungsi bagian sedimentasi

\begin{tabular}{|c|c|c|}
\hline $\begin{array}{c}\text { Fungsi } \\
\text { Bagian }\end{array}$ & Alt. 1 & Alt. 2 \\
\hline \hline SEDIMENTASI & TANK & $\begin{array}{c}\text { SARANG } \\
\text { TAWON }\end{array}$ \\
& -7 & \\
\hline
\end{tabular}

\subsection{Fungsi Bagian Filtrasi}

Proses koagulasi dipilih berdasarkan beberapa alternatif seperti tabel berikut:

\section{Tabel 6 Alternatif fungsi bagian filtrasi}

\begin{tabular}{|c|c|c|c|c|}
\hline $\begin{array}{l}\text { Fungsi } \\
\text { Bagian }\end{array}$ & Alt. 1 & Alt. 2 & Alt. 3 & Alt. 4 \\
\hline FILTRASI & 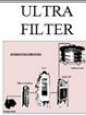 & 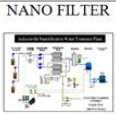 & $=$ & PASIR \\
\hline
\end{tabular}

\subsection{Fungsi Bagian Desinfeksi}

Proses koagulasi dipilih berdasarkan beberapa alternatif seperti tabel berikut:

Tabel 7 lternatif fungsi bagian desinfeksi

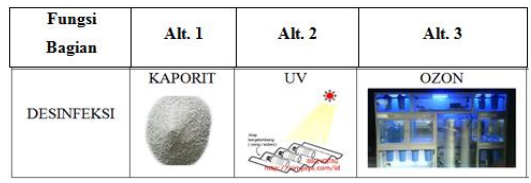

\subsection{Pembuatan Variasi Konsep}

Setelah pembagian fungsi dibuatkan variasivariasi yang merupakan gabungan dari fungsifungsi bagian tersebut.

Tabel 8 Kotak morfologi

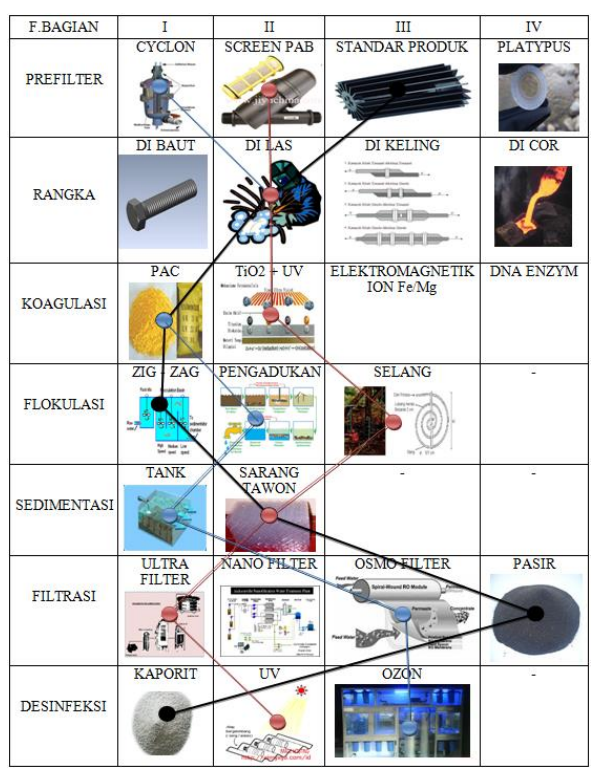

\subsection{Alternatif Fungsi Keseluruhan}

Adapun variasi-variasi konsep yang ada diterjemahkan kembali seperti terlihat pada gambar 4 dibawah:
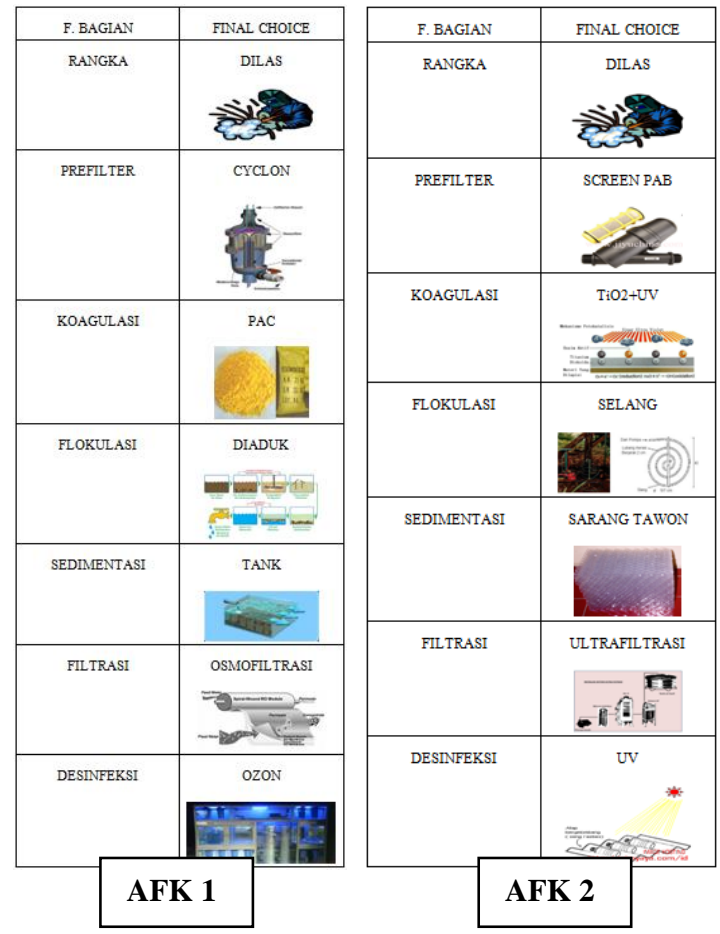

26 Yasin, Yuliar Erlangga, dkk; Perancangan Mesin Pengolah Air Bersih Bergerak Dengan Menggunakan Sistim Modular Untuk Penanggulangan Keadaan Darurat Air 


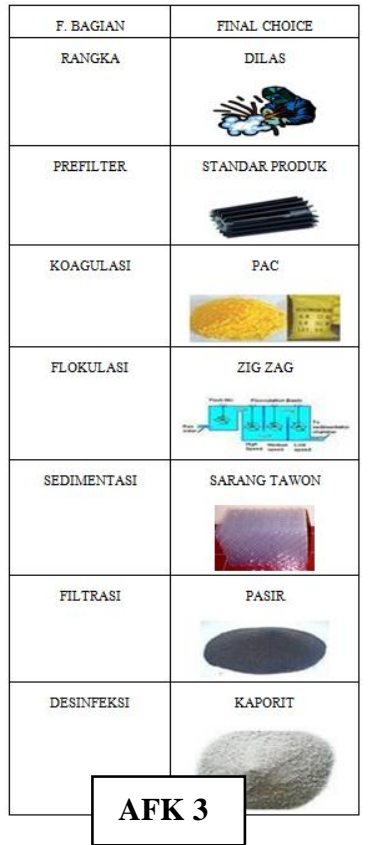

\section{Gambar 4 Alternatif fungsi keseluruhan}

\subsection{Penilaian Alternatif Fungsi Keseluruhan}

Ketiga alternatif tersebut dinilai untuk memperoleh alternatif fungsi keseluruhan terbaik.

\section{Tabel 9 Kriteria penilaian variasi prinsip}

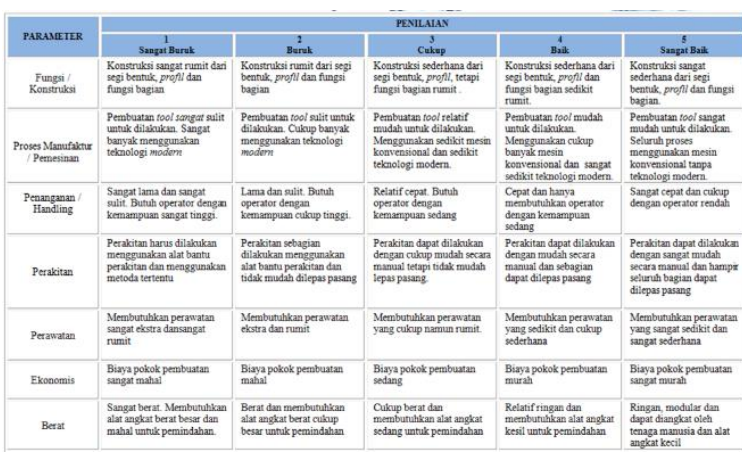

Tabel 10 Penilaian variasi prinsip

\begin{tabular}{|c|c|c|c|c|c|c|}
\hline \multirow{2}{*}{ No } & \multirow{2}{*}{$\begin{array}{l}\text { Aspek Yang } \\
\text { Dinilai }\end{array}$} & \multirow{2}{*}{$\begin{array}{c}\text { Bobot } \\
(\%)\end{array}$} & \multicolumn{3}{|c|}{ AFK } & \multirow{2}{*}{ Nilai Ideal } \\
\hline & & & AFK 1 & AFK 2 & AFK 3 & \\
\hline 1 & Fungsi & 50 & 4 & 5 & 5 & 5 \\
\hline 2 & Manufaktur & 15 & 3 & 3 & 4 & 5 \\
\hline 3 & Penanganan & 10 & 4 & 3 & 5 & 5 \\
\hline 4 & Perakitan & 10 & 3 & 3 & 4 & 5 \\
\hline 5 & Perawatan & 5 & 4 & 3 & 4 & 5 \\
\hline 6 & Biaya & 5 & 1 & 2 & 3 & 5 \\
\hline \multirow[t]{3}{*}{7} & Berat & 5 & 5 & 5 & 5 & 5 \\
\hline & \multicolumn{2}{|c|}{$\begin{array}{l}\text { Nilai total: ((Nilai AFK) } \\
x(\text { Bobot })) / 100\end{array}$} & 3,65 & 4.05 & 4,6 & 5,00 \\
\hline & $\begin{array}{l}\text { Prosentase: } \\
\text { Nilai total A } \\
\underline{\%} \\
\text { Nilai ideal to }\end{array}$ & $\mathrm{x} 100$ & $73 \%$ & $81 \%$ & $92 \%$ & $100 \%$ \\
\hline
\end{tabular}

\subsection{Konsep Pemecahan}

Berdasarkan aspek-aspek penilaian fungsi sebelumnya, maka fungsi kombinasi dari variasi konsep yang paling ideal dari ketiga alternatif fungsi keseluruhan adalah alternatif 3 , dengan prosentase $92 \%$, sehingga berdasarkan hasil tersebut dipilih rancangan-rancangan berdasarkan fungsi-fungsi dari alternatif 2 .

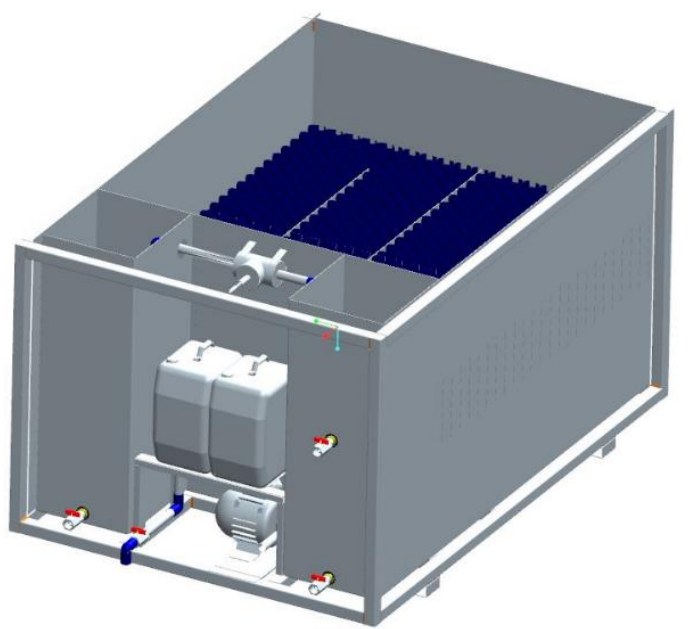

Gambar 5 Rancangan terpilih

1.12Pembuatan Draft Rancangan, Gambar Susunan dan Gambar Bagian

Tahapan penyelesaian akhir yang harus dilakukan adalah melakukan penggambaran gambar kerja detail dan gambar kerja susunan, yang nantinya akan digunakan sebagai informasi pada proses manufaktur. Selain itu gambar kerja detail dan gambar kerja susunan dapat juga dijadikan sebagai dokumen teknik. 


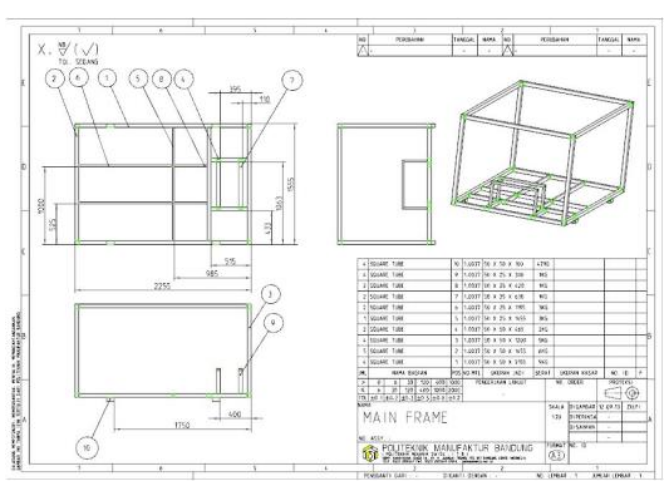

Gambar 6 Contoh dokumen teknik

\section{KESIMPULAN DAN SARAN}

\section{Kesimpulan}

Proses perancangan dan pembuatan compact mobile water treatment ini dapat terlaksana dan dapat diwujudkan menjadi sebuah produk yang diharapkan memiliki nilai guna bagi masyarakat khususnya yang mengalami keadaan darurat air

\section{Saran}

- Dilakukan penelitian untuk penentuan waktu yang tepat untuk melakukan backwash, dilihat dari nilai kekeruhan air olahan. Sehingga dapat ditentukan setelah pemakaian berapa kali backwash harus dilakukan.

- Pada penelitian selanjutnya perlu dikembangkan pengkajian menggunakan kontrol otomatis pada Mesin Pengolah Air Bersih Sistem mampu pindah ini.

- Perlu dikembangkan pengkajian terhadap waktu proses, sehingga dapat mempercepat proses pengolahan air besih. Mesin Pengolah Air Bersih Sistem Modular menghasilkan output $1 \mathrm{M} 3 / \mathrm{jam}$.

\section{DAFTAR PUSTAKA}

[1] Anonim. Water Chemistry \& Treatment. http://www.water-chemistry.in . (19 Juli 2011).

[2] Departemen Kesehatan RI. Keputusan Menteri Kesehatan RI Nomor 907/MENKES/ SK/VII/2002 tentang syarat-syarat dan pengawasan kualitas air minum. Jakarta: Departemen Kesehatan RI, 2002.

[3] H. Effendi. Telaah kualitas Air bagi Pengelolaan Sumber Daya dan Lingkungan Perairan. Yogyakarta: Kanisius, 2003

[4] A. Herlambang. "Teknologi Penyediaan Air Minum Untuk Keadaan Tanggap Darurat". Jurnal Air Indonesia, Vol.6, No.1, 2010.

[5] R.H. Indriatmoko dan W. Widayat. "Penyediaan Air Minum Pada Situasi Tanggap Darurat Bencana Alam".Jurnal Air Indonesia, Vol.3,No.1, 2007.

[6] Ministry of environment and forests.Status of Water Treatment Plans In India. http://www.cpcb.nic.in. (3 Agustus 2011).

[7] P. N. Raharjo. "Aplikasi Teknologi Pengadaan Air Bersih di Empat Desa Tertinggal di Bengkulu Selatan”. Jurnal Air Indonesia, Vol.3, No.1, 2007.

[8] Said, Nusa Idaman, Indriatmoko, Robertus Haryoto, Raharjo, P. Nugro, dan Herlambang, Arie. "Aplikasi teknologi pengolahan air sederhana untuk masyarakat pedesaan". Jurnal Air Indonesia, Vol.1, No.2, 2005. 